\title{
Corporate Tax Avoidance and Political Action Committee Contributions: An Empirical Analysis
}

Dr. Arthur D. Cassill, University of North Carolina at Greensboro

Dr. Gordian A. Ndubizu, Drexel University,

\begin{abstract}
This study examines the relationships between corporate tax avoidance and Political Action Committee (PAC) contributions. The study hypothesizes that corporate PAC contributions influence corporate tax avoidance behavior. However, the tax savings associated with corporate PAC contributions do not increase monotonically because of significant wealth transfers from voters to corporations and the subsequent brokering behavior of politicians in favor of the voter constituency. The results are consistent with our hypothesis.
\end{abstract}

\section{Introduction}

In recent years, corporate income tax avoidance(1) has been on the increase. The Joint Committee on Taxation and the Citizens for Tax Justice separately reported that despite increased corporate profitability in 1982, most large corporations successfully avoided paying federal income tax. Previous studies of corporate income tax avoidance have generally been concerned with measuring the equity effects of corporate income tax avoidance (e.g. Gravelle 1982 and 1983 and Stickney and McGee 1982) and/or identifying the corporations and industries affected by differential income tax avoidance (e.g. Stickney and Tower 1978, Siegfried 1974, and Zimmerman 1983). Only a few studies have provided a conceptual explanation of corporate tax avoidance (Cross and Shaw 1982). However, the Cross and Shaw (1982) model ignores the political realities of corporate tax lobbying behavior and the counterbalancing effects of the voter constituency on the tax legislative process that affects federal income tax policy.

This study examines the relationship between corporate tax avoidance and Political Action Committee (PAC) contributions. The study stresses that PAC contributions to members of the Senate Finance and the House Ways and
Means Committees increases corporate income tax avoidance for relatively low tax avoiding corporations. Extremely high tax avoiding companies realize no significant tax savings from their PAC contributions because of significant wealth transfers from individuals to corporations and the subsequent brokering behavior of the politician in favor of the voter constituency.

The remainder of the paper is organized as follows. In the next section the relationship between corporate tax avoidance and PAC contributions are discussed. Section 3 discusses the sample and the model applied in the study. The results of the study are reported in section 4 . Finally some concluding remarks are drawn in section 5.

\section{Corporate Tax Avoidance and PAC Contributions}

This study hypothesizes that PAC contributions to members of the Senate Finance and the House Ways and Means Committees may result in increased corporate income tax avoidance for relatively low tax avoiding corporations and have no effect on extremely high corporate tax avoid- 
ers. Durden and Silberman (1976), Chappell (1981), and Welch (1980) have found political action contributions to have a significant impact on Congressmen's voting patterns. These findings are consistent with the theory of economic regulation posited by Stigler (1971) and extended by Peltzman (1976) and Posner (1974). The theory asserts that the benefits from regulation motivate corporations to lobby for these benefits. One form of such lobbying includes PAC contributions to congressmen by corporate-related political action committees. Groups such as Common Cause and Citizens for Tax Justice among others, monitor PAC contributions to congressmen and the corporate tax rates corporations incur. Tax Notes as well as the Wall Street Journal have repeatedly discussed the issue of PAC contributions to tax legislators and the potential relationship that might exist (2). Empirical evidence also suggests such a relationship exists. Cassill (1986) provides empirical evidence that PAC contributions, after considering the level of income, are associated with decreases in industry income tax rates. The present study attempts to extend Cassill's study by examining specific corporations (rather than industries) who have been identified as corporate tax avoiders by Citizens for Tax Justice.

Politicians' reactions to PAC contributions are hypothesized to be consistent with McCormick and Tollison's (1981) assertion that legislation (of which the tax laws are included) is the result of a "brokering" function provided by politicians to various interest groups in the economy.

From a brokering standpoint, politicians are viewed as middlemen with the ability to accord wealth transfers to constituent groups. The brokering function is akin to the agency problem in that the broker/politician will behave as a normal, rational, wealth-maximizing agent for the constituent group/principal. Given the information and transaction costs associated with political influence, the voter constituency may be at a comparative disadvantage in the competition for wealth-transfers brokered by politicians. This is more likely to happen where the wealth-transfer from the voter constituency to corporations is not significant enough to arouse coalescing behavior by voters. The wealth transfer problem is compounded when the legislator perceived (or in reality, after getting "caught") tries to convince the voter constituency that by providing tax benefits to corporations, the voter constituency will benefit from more and better jobs, enhanced community wealth, and increased taxes, etc. The small number of firms enables them to better overcome free-rider problems associated with a constituency characterized by a more diverse set of objectives and views (3). Thus, information costs and transaction costs are relatively lower for corporations than they are for individual voters. Given the comparative disadvantage of the voter constituency, the politician has the incentive to deviate from his constituency's views without a significant loss of votes. The broker/politician acts favorably toward corporate tax legislation in exchange for PAC contributions. This implies that PAC increases corporate tax avoidance for relatively low tax avoiders.

On the other hand, if the voter constituency effects on politicians override the PAC effects, the hypothesized relationship between PAC and corporate tax avoidance may change. In this case PAC is expected to have no significant effect on corporate tax avoidance. The relationship between PAC contributions and corporate tax avoidance is more likely to occur for extremely high tax avoiding corporations because high corporate tax avoidance transfers a significant amount of wealth from the voter constituency to corporations (4). This wealth transfer stirs up social outcry thus creating a coalition of special interest groups on behalf of workers and other voter constituencies. The coalescing behavior of voters in turn minimize the information and transaction costs of dealing with politicians and increases the marginal cost of votes for politicians who broker for corporations. Thus, politicians may tend to broker for the voter constituency despite PAC contributions from extremely high corporate tax avoiders. The hypotheses tested are as follows:

$\mathbf{H}_{\mathbf{1}}$ : $\quad$ PAC contributions increase corporate income tax avoidance for relatively low tax 
avoiding corporations.

$\mathbf{H}_{2}:$ PAC contributions have no significant effect on corporate income tax avoidance for extremely high tax avoiders.

\section{Sample}

The initial sample of firms was obtained from the firms listed in the Corporate Taxpayers and Corporate Freeloaders (Citizens for Tax Justice, August, 1985). To be selected, corporations had to meet three additional selection criteria: (1) a December 31 fiscal year-end, (2) financial data available on the Compustat Annual Industrial Tape from 1980-1985, and (3) Political Action Committee (PAC) contributions to members of the House Ways and Means Committee and the Senate Finance Committee available on the Federal Election Committee's Non-Party Report on Financial Activity tape 1981-1982. The data obtained from the Citizens for Tax Justice monograph were cross-examined with the Compustat data. There was no evidence of any material differences. The sample is broken down into two groups: (1) High Income Tax Avoiders group and (2) Low Income Tax Avoiders group. The high avoider group consists of corporations that enjoyed a tax rebate (paid negative income tax) in 1982 despite the fact that they reported positive pre-tax accounting income (5). The low avoiders group paid corporate income taxes to the IRS but had an effective tax rate at least $15 \%$ below the statutory tax rate of $46 \%$. Careful attention was paid to select high avoiders whose pre-tax accounting income was not significantly different from the low tax avoiders. This procedure prevents including corporations with negative pre-tax accounting income (losses) in the high avoiders group. These selection criteria resulted in a sample of 137 firms for 1982 .

The high avoiders group is further divided into extremely high tax avoiders and marginally high tax avoiders based on the absolute mean effective tax rate of $20 \%$ (6). The high tax avoiders whose absolute effective tax rate is greater or equal to $20 \%$ are considered extremely high tax avoiders; otherwise the firms are classified as marginally high tax avoiders.

The high and low income tax avoiders were matched on the basis of pre-tax accounting income. Table 1 provides a summary of statistics on the sampled firms. The mean pre-tax accounting income for low and high avoiders are 368 million dollars and 306 million dollars, respectively. This is not a positive pre-tax accounting income. Further attempts were made to match the sample groups on the basis of depreciation expenses, capital expenditures, investment tax credit and total assets. The overall results show that the low avoiders and extremely high avoiders are fairly distributed across variables. The high avoiders and marginally high avoiders seem to differ slightly from the low avoiders based on depreciation expenses and total assets. This is not expected to be a problem since the results of the regression specification error test show that the models employed in the study are not misspecified (see specification test statistics in Table 2 and 3). The selection criteria employed resulted in 85 high avoiders and 53 low avoiders. The mean PAC contribution for high avoiders is $48 \%$ greater than the mean PAC for low avoiders.

\section{Model of Tax Avoidance}

The relationships between corporate income tax avoidance and the PAC contribution to members of Senate Finance and House Ways and Means Committees are expressed as follows:

$\mathrm{CTA}=\mathrm{a}+$ bIncome $+\mathrm{cPAC}$

where:

CTA = corporate tax avoidance; surrogate with taxes payable/rebate for 1982

Income $=1982$ pre-tax corporate income

PAC $=$ Political Action Committee Contribution to members of the Senate Finance and the House Ways and Means Committee for 1982. Lagged PAC has no significant effect on corporate income tax avoidance. 
Table I

Summary statistics for the sampled Firms

\begin{tabular}{|c|c|c|c|c|}
\hline \multirow[b]{2}{*}{ Sample Groups } & \multicolumn{2}{|r|}{ Mear } & \multicolumn{2}{|c|}{ Statistics for 1982} \\
\hline & $\begin{array}{l}\text { Pre-Tax } \\
\text { Income }(\mathrm{m})\end{array}$ & $\begin{array}{l}\text { Taxes } \\
\text { Paid (m) }\end{array}$ & $\operatorname{PAC}(\mathrm{m})$ & $\mathrm{N}$ \\
\hline Low Avoiders & 368.34 & 79.56 & 0.036 & 53 \\
\hline $\begin{array}{l}\text { High Avoiders } \\
\text { Extreme High Avoiders } \\
\text { Marginal High Avoiders }\end{array}$ & $\begin{array}{r}306.17 \\
96.56 \\
428.77\end{array}$ & $\begin{array}{l}-33.05 \\
-40.89 \\
-28.46\end{array}$ & $\begin{array}{l}0.068 \\
0.056 \\
0.075\end{array}$ & $\begin{array}{l}84 \\
31 \\
53\end{array}$ \\
\hline & & Mean & statistics & for 1982 \\
\hline Sample Groups & $\begin{array}{l}\text { epreciation } \\
\text { Expense }\end{array}$ & $\begin{array}{l}\text { Capital } \\
\text { Expenditure }\end{array}$ & $\begin{array}{l}\text { Investment } \\
\text { Tax Credit }\end{array}$ & $\begin{array}{l}\text { Total } \\
\text { Assets }\end{array}$ \\
\hline Low Avoiders & $1,399.34$ & 464.88 & 25.14 & $5,111.47$ \\
\hline $\begin{array}{l}\text { High Avoiders: } \\
\text { Extreme High Avoiders } \\
\text { Marginal High Avoiders }\end{array}$ & $\begin{array}{l}1,675.61 \\
1,452.87 \\
1,805.90\end{array}$ & $\begin{array}{l}549.17 \\
482.95 \\
587.91\end{array}$ & $\begin{array}{l}30.39 \\
26.07 \\
32.91\end{array}$ & $\begin{array}{l}6,016.06 \\
5,304.77 \\
6,432.10\end{array}$ \\
\hline
\end{tabular}

Note: $\quad N$ is the number of companies in each group. $M$ is millions of dollars. PAC is the Political Action Committee contribution to members of the senate Finance and the House Ways and Means Committees.

\begin{abstract}
Negative taxes paid refers to tax rebate obtained by carrying back excess tax deductions and credits to an earlier year and receiving a tax refund from IRS. The positive taxes paid refers to 1982 federal income tax payable. The sampled firms are fairly distributed across industry (SIC two digit).
\end{abstract}

The dependent variable in equation 1, CTA, is difficult to quantify. The 1982 federal income taxes payable to the IRS or rebate received from the IRS was used to measure corporate tax avoidance. The high tax avoiding companies received tax rebates whereas the low avoiders paid federal income tax but not at the statutory rate of $46 \%$. Corporate taxes payable or avoided depends in part on the level of income. For high corporate tax avoiders, the coefficient of income is expected to have a negative sign; for low avoiders, a positive sign (see definition of high and low avoiders). The model of corporate tax avoidance suggests that PAC contributions impact corporate tax avoidance through their influence on politicians' brokering functions. The politician would broker favorably towards low tax avoiders because of the relatively lower wealth-transfer against the voter constituency. Thus the coefficient of PAC contributions for low avoiders would have a negative sign. For high tax avoiders, the voter constituency effects exceed the PAC effects because of significant wealth transfers from the voter constituency to corporations (7). Thus, PAC contributions will have an insignificant effect on corporate tax 
avoidance for extremely high avoiders.

Equation 1 did not consider the possible joint effect of income and PAC on corporate tax avoidance. Cassill (1986) found the interaction of income and PAC to have a significant impact on industry taxes paid. To model the joint effects of income and PAC contributions on tax avoidance, equation 1 is rewritten as follows:

$\mathrm{CTA}=\mathrm{a}+$ Bincome + CPAC + dIncome $*$ PAC (2)

Equations 1 and 2 are fitted cross-sectionally. A common problem confronting this type of analysis is heteroscedastic error terms. The Glejser (1969) test as modified by Goldfeld and Quandt (1972) was applied to check for heteroscedasticity (8). To implement the Goldfeld and Quandt test, the square residuals were regressed on the independent variables. An alternative approach consists of regressing the squared residuals on the squares of the regressors. Both forms of the Goldfeld and Quandt tests were performed. The preliminary results suggest that equations 1 and 2 suffer from heteroscedastic error term. The intercept term on the Goldfeld and Quandt models are not significant while the coefficients of the regressors are statistically significant at the 0.05 level. To deal with this problem, equations 1 and 2 were re-estimated using transformed data (9). The Goldfeld and Quandt test was re-applied on the transformed equations. There is no evidence of either classical or mixed heteroscedasticity on the new equations. Both the intercept term and the coefficients of the regressors in the Goldfeld and Quandt models are not significant at the 0.05 level.

Careful attention is paid to the specification of equations 1 and 2. The RESET (regression specification error test) procedure suggested by Ramsey (1969) and extended by Thursby (1985), Hausman (1978), and Thursby and Schmidt (1977) was applied to check for omitted variables and incorrect functional form (10). The results of the RESET test are reported in Tables 2 and 3. The RESET $F$ statistics are not signifi- cant at the 0.05 level, implying that the models are not misspecified. This result indicates that industry and size factors are not relevant explanatory variables of equations 1 and 2 . The result is not surprising given that the sample was matched on the basis of total assets, investment tax credit and two digit SIC codes. The RESET results increase the confidence on the profile analysis in Table 1.

\section{Empirical Results}

Tables 2 and 3 display the results of estimating equations 1 and 2 , respectively. In both equations the constant term, alpha, is not suppressed. Cassidy (1981, p. 148) stresses that suppressing the constant term violates the classical linear regression assumption that the mean of the error term is zero (11). The violation of the linear regression assumption results in estimates of slope coefficients that are biased and have inflated t-statistics. The intercept term absorbs the mean effect of omitted variables, preventing the model from being misspecified.

The impact of income on corporate tax avoidance is examined next. The coefficients of income are statistically significant for all groups in equations 1 and 2 . The sign of the coefficients of income varies between high and low avoiders. The low avoiders have a positive sign, implying that they paid some corporate income tax. Negative income coefficients are observed for the high avoiders. These signs are consistent with the expected results. The coefficient of income for low avoiders ranges from 0.31 in equation 1 to 0.34 in equation 2 . Including the interaction term in equation 2 does not significantly change the coefficient of income in equation 1 . The high avoiders have income coefficients that range from -0.059 in equation 1 to 0.092 in equation 2. These coefficients are not significantly different, despite the inclusion of the interaction term. Similar results are observed for extremely and marginally high avoiders groups.

The impact of PAC contributions on corporate tax avoidance is examined in Tables 2 and 3. 
Table 2

Relationship Between Explanatory Variables and Corporate Tax Avoidance

\begin{tabular}{|c|c|c|c|c|c|}
\hline \multirow[b]{2}{*}{ Sample Groups } & \multirow[b]{2}{*}{ alpha } & \multicolumn{4}{|c|}{ Coefficients of Equation 1} \\
\hline & & bIncom & CPAC & & $R^{-2}$ \\
\hline $\begin{array}{l}\text { Low Avoiders } \\
\text { T-Value } \\
\text { I-Tailed Prob. }\end{array}$ & $\begin{array}{l}-26.800 * \\
(-1.51) \\
0.068\end{array}$ & $\begin{array}{r}0.31 \\
(15.09 \\
0.00\end{array}$ & $\begin{array}{r}-2373 \\
(-1 \\
0\end{array}$ & $\begin{array}{l}.85 * \\
.36) \\
.000\end{array}$ & 82.2 \\
\hline $\begin{array}{l}\text { High Avoiders } \\
\text { T-Value } \\
\text { I-Tailed Prob. }\end{array}$ & $\begin{array}{r}-21.889 \\
(-2.99) \\
0.001\end{array}$ & $\begin{array}{rl}-0 & .0 \\
(-34 & .8 \\
0.0\end{array}$ & $\begin{array}{l}059 \\
82) \\
000\end{array}$ & $\begin{array}{l}.613 \\
.42) \\
.000\end{array}$ & 93.9 \\
\hline $\begin{array}{c}\text { Extreme High Avoiders } \\
\text { T-Value } \\
\text { I-Tailed Prob. }\end{array}$ & $\begin{array}{r}-26.834 \\
(-3.83) \\
0.000\end{array}$ & $\begin{array}{r}-0.1 \\
-4.4 \\
0.0\end{array}$ & $\begin{array}{r}117 \\
10 \\
0\end{array}$ & $\begin{array}{l}.136 * \\
.23) \\
.411\end{array}$ & 42.4 \\
\hline $\begin{array}{l}\text { Marginal High Avoiders } \\
\text { T-Value } \\
\text { l-Tailed Prob. }\end{array}$ & $\begin{array}{r}-9.057 \\
(-1.89) \\
0.032\end{array}$ & $\begin{array}{rl}-0 & .0 \\
-39 & .0 \\
0.0 & 0\end{array}$ & $\begin{array}{r}917 \\
(3 . \\
0\end{array}$ & $\begin{array}{l}.294 \\
.53) \\
.000\end{array}$ & 97.0 \\
\hline \multicolumn{6}{|c|}{ Specification Test statistics } \\
\hline $\begin{array}{l}\text { Low Avoiders RESET } \\
\text { High Avoiders RESET }\end{array}$ & $\begin{array}{l}F=2.05 \\
F=0.51\end{array}$ & $\begin{array}{l}F(2,5 \\
F(2,8\end{array}$ & $\begin{array}{l}50, .05) \not \\
81, .05) \not\end{array}$ & $\begin{array}{l}3.18 \\
3.11\end{array}$ & \\
\hline \multicolumn{6}{|c|}{$\begin{array}{c}\text { *Not significant at the } 0.05 \text { percent level. } \mathrm{R}^{-2} \text { is the } \\
\text { coefficient of determination adjusted for degrees of freedom. } \\
\text { Table } 3\end{array}$} \\
\hline $\begin{array}{l}\text { Impacts of Interaction } \\
\text { Avoidance }\end{array}$ & of Expla & anatory $\mathrm{V}$ & Variables o & on Corpor & ate Tax \\
\hline Sample Groups & alpha & bIncome & $\begin{array}{l}\text { dIncome } \\
\text { CPAC }\end{array}$ & ts of Equ & $\overline{\operatorname{tion} 2}$ \\
\hline $\begin{array}{l}\text { Low Avoiders } \\
\text { T-Value } \\
\text { l-Tailed Prob. }\end{array}$ & $\begin{array}{r}-36.947 \\
(-2.51) \\
0.008\end{array}$ & $\begin{array}{r}0.336 \\
(16.42) \\
0.000\end{array}$ & $\begin{array}{r}4127.617 \\
(1.72) \\
0.046\end{array}$ & $\begin{array}{r}-13.712 \\
(3.78) \\
0.000\end{array}$ & 85 \\
\hline $\begin{array}{l}\text { High Avoiders } \\
\text { T-Value } \\
\text { l-Tailed Prob. }\end{array}$ & $\begin{array}{c}-16.913 \\
(-2.23) \\
0.014\end{array}$ & $\begin{array}{r}-0.092 \\
(-5.36) \\
0.000\end{array}$ & $\begin{array}{c}429.205^{*} \\
(1.56) \\
0.061\end{array}$ & $\begin{array}{r}1.691 \\
(1.89) \\
0.031\end{array}$ & 94 \\
\hline $\begin{array}{c}\text { Extreme High Avoiders } \\
\text { T-Value } \\
\text { I-Tailed Prob. }\end{array}$ & $\begin{array}{c}-23.617 \\
(-3.06) \\
0.003\end{array}$ & $\begin{array}{r}-0.183 \\
(-4.26) \\
0.000\end{array}$ & $\begin{array}{c}-624.468^{*} \\
(-0.75) \\
0.231\end{array}$ & $\begin{array}{l}5.518 * \\
(1.14) \\
0.133\end{array}$ & 45 \\
\hline $\begin{array}{l}\text { Marginal High Avoiders } \\
\text { T-Value } \\
\text { 1-Tailed Prob. }\end{array}$ & $\begin{array}{c}-3.887^{*} \\
(-0.68) \\
0.250\end{array}$ & $\begin{array}{r}-0.089 \\
(-4.14) \\
0.000\end{array}$ & $\begin{array}{r}621.640 \\
(1.70) \\
0.047\end{array}$ & $\begin{array}{l}1.342 * \\
(1.18) \\
0.121\end{array}$ & 97 \\
\hline
\end{tabular}

Specification Test statistics

Low Avoiders RESET $F=1.98 \quad F(2,49, .05) \not 3.18$

High Avoiders RESET F $=0.51 \quad \mathrm{~F}(2,80, .05) \not 3.11$

*Not significant at the 0.05 percent level. $R^{-2}$ is the

coefficient of determination adjusted for degrees of freedom. 
For low avoiders, the coefficient of PAC in equation (1) is negative and not statistically significant at the 0.05 level. Although the coefficient of PAC has the correct sign, the hypothesis that PAC decreases corporate tax liability is rejected at the 0.05 level. This result is not consistent with the results of estimating equation (2) for low tax avoiders reported in Table 3. The coefficient of the interaction of income and PAC [Income*PAC] for low avoiders has the correct sign and is significant at the 0.05 level. This result suggests that at various income levels PAC purchases significant tax savings to corporations. The result is consistent with the hypothesis that PAC decreases corporate tax liabilities for low income tax avoiders.

The coefficient of PAC for high avoiders is shown in Table 2. The results show that PAC has a statistically significant positive coefficient. This result suggests that PAC increases the corporate tax rebate. The combination of extremely high avoiders and marginally high avoiders into a single high avoiders group may influence the observed results. In addition, an appropriate test of the second hypothesis requires further separating of the high avoiders group into extremely high avoiders and marginally high avoiders groups. The results for extremely high avoiders and marginally high avoiders are reported in Table 2. The results for marginally high avoiders are not different from the high avoiders group. The coefficient of PAC for the marginally high group is 917.29 and significant at the 0.05 level. The extreme high avoiders has a PAC coefficient that is not statistically significant at the 0.05 level.

This result is consistent with the hypothesis that PAC has no significant effect on corporate tax avoidance for extremely high tax avoiders.

Similar results were observed for the coefficient of Income*PAC in Table 3. Extremely high avoiders group has an insignificant coefficient of Income*PAC, indicating that the interaction of income and PAC has no effect on corporate tax rebate. Similarly, the coefficient of PAC for extreme avoiders in equation (2) is not statistically significant at the 0.05 level. These results indicate that PAC has no significant tax benefit for extremely high corporate income tax avoiders. In the extremely high tax avoiders case, the significant wealth-transfer from the voter constituency to corporations would necessitate coalition formation among voters. This coalition would in turn minimize the voter's information and transaction costs of dealing with the politicians. The coalescing behavior of the voters would increase the politicians' marginal cost of legislating or maintaining favorable corporate tax laws. Given that the politicians are behavior optimizers, they would legislate tax laws that favor their voter constituency. Thus, PAC contributions for extremely high corporate tax avoiders would have little or no tax benefit.

The low tax avoiders and marginally high tax avoiders, on the other hand, have favorable tax savings as a consequence of PAC contributions. The implication of these results is that the tax savings associated with PAC do not increase monotonically. There is a level of corporate tax avoidance at which PAC generates tax savings and a level beyond which PAC has no impact on corporate tax liability.

\section{Implications and Conclusions}

This study examines the relationships between corporate tax avoidance and PAC contributions to members of Senate Finance and House Ways and Means Committees. The results indicate that the level of corporate income tax avoidance and PAC contributions are related, but that the tax savings associated with successful political participation through the use of PAC contributions in an effort to influence tax legislators do not increase monotonically. The results also support the view that the politicians may deviate somewhat from the desires of their voter constituencies by brokering wealth transfers in the form of favorable corporate income tax legislation in return for corporate PAC contributions, but only to the extent that the marginal benefit associated with such action exceeds the marginal cost. The marginal cost increases for politicians when their voter constituency become more fully aware of 
the significant wealth transfers that have been brokered away from them in favor of corporations.

The cost manifests itself in fewer votes, increased public pressure, and social criticism. In effect, the ability of interest groups to influence tax legislators' decision process supports the notion that politicians are behaving as normal, wealth-maximizing individuals to the extent that the law permits such behavior.

Finally, the research results hold implications for the development of future income tax policy.
First, it becomes necessary to understand that the formulation and implementation of an effective income tax policy must consider the impact of the legislative process as it exists, as well as the effect of current and proposed campaign financing laws upon that process. If favorable tax legislation can be brokered to accommodating firms at the expense of individuals and other firms, equity and compliance with the income tax system becomes more difficult to achieve. Second, corporations may in the long run come to view PAC contributions as a normal cost of "doing business". This view of PAC contributions may result in an inefficient allocation of scarce resources.

Footnotes

Tax avoidance involves the rearrangement of economic activities to increase the amount of income which legally avoids tax, increase the amount of income subject to lower tax rates, and/or to defer the tax liability to reduce the effective tax rate below the statutory rate of 46 percent.

For instance, refer to related articles in Tax Notes dated December 30, 1985 and February 17, 1986 and in the WSJ, September 23, 1988, June 7, 1988, and December 3, 1984.

The free-rider problem refers to the failure of individuals to participate in profitable coalescing activities. The House Ways and Means Committee reports that "Certain tax provisions allow many corporations to pay relatively little federal income tax without stimulating investment and production as intended. Many firms have made use of tax provisions to reduce their tax liability to zero, and, in come cases, obtain a tax refund. See the Committee report on the Tax Reform Act of 1985 (December 7. 1985).

High income tax avoiders enjoy a tax rebate, usually obtained by carrying back excess tax deductions and credits to an earlier year and receiving a tax refund check from the U. S. Treasury Department. The low avoiders had some federal income tax payable in 1982.

Effective tax rate is taxes/refund divided by profit. The high tax avoiders have negative tax rate [see Citizens for Tax Justice - Corporate taxpayers and Corporate freeloaders, August 1985].

Given the balanced budget goal, if corporate tax revenue decreased significantly, the government may cut social spending, increase individual income taxes, or initiate different types of sales taxes.

In this analysis two heteroscedastic forms were tested: $2=b+\mathrm{Bi}^{2}+\mathrm{bPAC}^{2}$; and $\mathrm{e}^{2}=\mathrm{b}+\mathrm{Bi}+\mathrm{BPAC}$; where: $\mathrm{e}=$ $\mathrm{CTA}-(\mathrm{a}+\mathrm{Bi}+\mathrm{CPAC})$

$/ \mathrm{e}^{2}$ is used to transform the data

To implement the RESET procedure, the fitted values of the dependent variable (CTA) are estimated from the model under examination. Then CTA 2 and CTA 3 are used as two additional regressors in the second equation. An F Test is then carried out to assess the joint significance of the added variables.

The constant term absorbs the mean effect of a number of variables which are not significant enough to be included as a regressor in the equation. This function of the constant term prevents the error term from having a mean that is different from zero. [Cassidy, H. 1981].

\section{References}

Allingham, Michael G. and A. Sandmo, "Income Tax Evasion: A Theoretical Analysis," Journal of Public Economics, I (Nov. 1972), 323-338.

Cassidy, Henry, Using Econometrics: A Beginner's Guide, Reston Publishing Company, Inc., 1981.

Cassill, A. D. The Influence of Political Action Committee Contribution Upon Industry Tax Rate. Ph.D. Dissertation University of Tennessee, 1986.

Christiansen, V., "Two Comments on Tax Evasion," Journal of Public Economics (1980), 389-393.

Chappell, H., Jr., "Campaign Contributions and Voting on the Cargo Preference Bill: A Comparison of Simultaneous Models," Public Choice, 36 (1981), 301-312. 
6 Citizens for Tax Justice, Corporate Taxpayers and Corporate Freeloaders. Citizens for Tax Justice, August 1985.

7 Crane, S. and F. Nourzad, "Inflation and Tax Evasion: An Empirical Analysis," The Review of Economics and Statistics, May 1986, 217-223.

8 Cross, R. and G. K. Shaw, "On the Economics of Tax Aversion," Public Finance, 36 (1982), 36-47.

9 Durden, G. and J. Silberman, "Determining Legislative Preferences for the Minimum Wage: An Economic Approach," Journal of Political Economy, 84 (April 1976), 317-329. Glejser, H., "A New Test for Heteroscendasticity," Journal of the American Statistical Association, 64 (1969), 316323.

11 Goldfeld, S. M. and R. E. Quandt, Nonlinear Methods in Econometrics, Amsterdam: North Holland Publishing Co., 1972.

Grander, C. W. and P. Newbold, Forecasting Economic Time Series New York, Academic Press, 1977. Gravelle, J. G. "Capital Income Taxation and Efficiency in the Allocation of Investment." National Tax Journal, May 1983, 297-306.

. "Effects of the 1981 Depreciation Revisions on the Taxation of Income from Business Capital." National Tax Journal, March 1982, 1-20.

Harvey, J. A., The Econometric Analysis of Time Series, Oxford: Phillip Allen, 1981.

Hausman, J. A., "Specification Tests in Econometrics," Econometrica, 46 (Nov. 1978), 1251-1270.

Judge, George, W. E. Griffiths, R. C. Hill, and T. Lee. The Theory and Practice of Econometrics, New York: Wiley, 1980.

McCormick, R. E. and

Peltzman, S., "Toward a More General Theory of Regulation," The Journal of Law and Economics (August 1976), 211-240.

Posner, R. A., "Theories of Economic Regulation," The Bell Journal of Economics and Management Science (Autumn 1974), 335-358.

Ramsey, James B., "Test for Specification Errors in Classical linear Least Squares Regression Analysis," Journal of the Royal Statistical Society (1969), 350-351.

Siegfried, J. J. "Effective Average vs. Corporation Income Tax Rates." National Tax Journal (1974), 245-259. Spicer, M. and Lee A. Becker, "Fiscal Inequity and Tax Evasion: An Experimental Approach," National Tax Journal (June 1980), 171-175. Spinivasam, T. N., "Tax Evasion: A Model," Journal of Public Economics, 2 (1973), 339-349.

Stigler, G. J., "The Theory of Economic Regulation," The Bell Journal of Economics and Management Science (Spring 1971), 3-21.

Stickney, C. P. and V. E. McGee. "Effective Corporate Tax Rates: The Effect of Size, Capital Intensity, leverage and Other Factors." Journal of Accounting and Public Policy, 1982, 125-152. Stickney, C. P. and R. B. Tower, Jr., "Effective Income Tax Rates of Petroleum Companies." Oil and Gas Quarterly, 445-456.

Thursby G., "The Relationship Among the Specification Test of Hausman, Ramsey, and Chow," Journal of the American Statistical Association, 80 (Dec. 1985), 926-928.

30 Thursby G. and T. Schmidt, "Some Properties of Test for Specification Error in Linear Regression Model,1" Journal of the American Statistical Association, 72 (Sept 1977), 635-641. 